Jurnal Konstruksi Hukum | ISSN: XXXX | E-ISSN: XXXX Vol. 1, No. 2, Oktober 2020, Hal. 384-387| Available online at https://www.ejournal.warmadewa.ac.id/index.php/jukonhum DOI: https://doi.org/10.22225/jkh.1.2.2544.384-387

\title{
PERJANJIAN PINJAM NAMA SEBAGAI BENTUK KEPEMILIKAN TANAH OLEH WARGA NEGARA ASING DI BALI
}

\author{
I Komang Gede Suwanjaya, I Nyoman Sumardika, Ni Made Puspasutari Ujianti \\ Fakultas Hukum Universitas Warmadewa, Denpasar-Bali, Indonesia
}

\begin{abstract}
Abstrak
Perjanjian pinjam nama adalah perjanjian yang belum ada pengaturannya secara khusus dalam Kitab UndangUndang Hukum Perdata (KUHPerdata), tetapi tumbuh dan berkembang dimasyarakat. Perjanjian pinjam nama ini masuk ke dalam perjanjian khusus atau sering disebut perjanjian inominaat. Berdasarkan latar belakang tersebut, penelitian ini dilakukan dengan tujuan mendeskripsikan pengaturan perjanjian pinjam nama sebagai bentuk kepemilikan tanah oleh warga negara asing di Bali dan pertanggungjawaban notaris dalam pembuatan akta perjanjian atas penguasaan tanah oleh warga negara asing di Bali. Metode penelitian menggunakan penelitian hukum normatif. Berdasarkan temuan penelitian diketahui bahwa tidak adanya pengaturan secara khusus mengenai perjanjian pinjam nama yang diatur dalam undang-undang (KUHPerdata). Selama para pihak bisa menjalankan perjanjian dengan baik sesuai ketentuan Undang-Undang tentang sahnya perjanjian dan mengenai hak milik atas tanah yang sudah diatur di dalam KUHPerdata dan Undang-Undang Pokok Agraria (UUPA), perjanjian tersebut sah di mata hukum. Selanjutnya, pertanggungjawaban dan tugas dari notaris sudah diatur dalam Undang-Undang Jabatan Notaris (UUJN). Kepemilikan tanah oleh WNA dengan berdasarkan pada akta pinjam nama merupakan perbuatan yang dilarang atau bertentangan dengan hukum. Pelanggaran terhadap pasal-pasal yang dimaksud dalam Pasal 84 UUJN tersebut merupakan pelanggaran terhadap syarat-syarat formil pembuatan akta otentik. Pemerintah harus melakukan pengawasan terhadap perjanjian tidak bernama ini karena perjanjian ini merupakan penyelundupan hukum.
\end{abstract}

Kata Kunci: Kepemilikan Tanah; Notaris; Perjanjian Pinjam Nama

\begin{abstract}
A nominee agreement is an agreement that has not been specifically regulated in the Civil Code, but grows and develops in the community. The agreement is included in a special agreement or often called an innominate agreement. Based on this background, this research was conducted with the aim of describing the arrangement of nominee agreements as a form of land ownership by citizens in Bali and the responsibilities of notaries in drafting agreement deeds for land tenure by foreign nationals in Bali. The research method used was normative legal research. Based on the results, it was revealed that there was no specific regulation regarding the nominee agreement which was regulated in the Civil Code. As long as the parties are able to carry out the agreement properly in accordance with the provisions of the law regarding the validity of the agreement and regarding land ownership rights that have been regulated in the Civil Code and the Basic Agrarian Law, the agreement is valid before the law. Furthermore, the responsibilities and duties of a notary have been regulated in the Law on Notary Position. the ownership of land by a foreigner based on a nominee agreement is an act that is prohibited or against the law. The violation of the articles referred to in Article 84 of the Notary Position Law is a guarantee of the formal requirements for making an authentic deed. The government must supervise this anonymous agreement because this agreement is legal smuggling.
\end{abstract}

Keywords: Land Ownership; Notary; Nominee Agreement

\section{PENDAHULUAN}

Indonesia memiliki suatu asas nasionalitas tentang hak atas tanah diamana tanah merupakan salah satu suber daya alam yang paling utama kebutuhan atas tanah tersebut tidak hanya menarik untuk rakyat idonesia saja, melainkan para investor asing juga ingin memiliki atau menanamkan modalnya (investasi) di Indonesia (Harsono, 2002). Undang-Undang Pokok Agraria adanya pengaturan secara khusus mengenai hak atas tanah dimana WNA tidak boleh memiliki ataupun menguasai tanah di 
Indonesia dari sektor pariwisata khususnya di Bali dalam menjalankan bisnisnya. Hal ini menunjukan bahwa warga Negara Asing saja yang berhak memiliki atau mempunyai hak milik atas tanah di Indonesia. Adanya pengaturan khusus seperti itu pihak warga Negara Asing merasa ragu atau tidak puas terhadap keterbatasan hak milik yang di oleh pemerintah.

Dalam perjanjian ini warga Negara Asing hanya biasa memiliki hak pakai saja dalam suatu perjanjian tidak diperbolehkan menguasai dan memiliki hak atas tanah karena itu warga Negara Asing hanya mempunyaui hak pakai atas banguanan (HGB) itupun adanya jangka waktu yang harus di taati yaitu sekitar 20 tahun bisa di perpanjang samapai 25 tahun dan seterusnya, jika warga Negara Asing melanggar jangka waktu tersebut ingin memiliki selama-lamanya itu disebut suaatu penyulundupan hukum atau batal demi hukum.

Warga negara asing yang sudah memahami potensi dan pembangunan di bidang ekonomi khususnya perkembangan sektor pariwisata diIndonesia, melihat peluang keuntungan dalam bisnis pariwisata yang mendukung (Hutauruk \& Harto, 2017). Anggapan mengenai nilai jual tanah di Bali berstatus hak milik akanlebih besar dibandingkan dengan hak sewa dan hak pakai, hal tersebut dirasa memberi keuntungan lebh bagi warga asing. Fenomena tersebut membuat warga asing tertarik untuk berupaya memiliki hak atas tanah di Bali, dengan melakukan berbagai macam cara salah satu cara yang dilakuakan yaitu dengan melakukan perjanjian pinjam nama di dalam perjanjian ini melibatkan warga negara asing dan warga negara Indo. Warga negara asing meminjam nama warga negara Indonesia guna melakukan pelanggaran atau penyelundupan hukum, agar warga negara asing ini mempunyai hak secara penuh atas tanah dalam proses jual beli yang dilakukan oleh warga negara asing. Perjanjian pinjam nama ini rentan sekali terjadi sengketa atau permasalahan karena perjanjian ini merupakan perjanjian yang belum diatur secara khusus di dalam hukum positif (Amalia, 2018).

Hal yang lumrah terjadi ketika para pihak membuat perjanjian antara warga negara Indonesia dengan warga negara asing, secara de jureapabila perjanjian telah dilakukan dan disepakati para pihak, maka objek perjanjian berupa tanah tersebut telah dimiliki oleh warga negara Indonesia. Secara de factoberlaku sebaliknya yakni objek tersebut menjadi milik warga negara asing. Warga Negara Indonesiajuga biasa dikatakan wanprestasi, dengan mengakui tanah tersebut miliknya dan menjualnya tanpa sepengetahuan warga negara asing (Winardi, 2017). Hal tersebut akan menimbulkan konflik bagi para pihak, sebab warga negara asing yang merasa rugi dan melakukanpenuntutan atas tanah tersebut yang telah dibeli dengan harta kekayaannya sendiri. Jika dianalisis lebih lanjut dalam peralihan hak dalam pembebanan ini berkaitan dengan peran Notaris yang turut serta cukup besar, dimana pihak yang terlibat sadar dan memahami bahwa sannya hal tersebut bertentangannorma hukum, hal tersebut biasa dilakukan dan menyalahgunakan kuasa mutlak di dalam perjanjian pinjam nama akan berdampak, apabila salah satu pihak melakukan wanprestasi (Subekti, 2002).

Ada beberapa penelitian terdahulu yang relevan dengan penelitian ini yaitu penelitian yang mengkaji tentang perjanjian nomine dalam kepemilikan tanah bagi warga Negara Asing yang berkedudukan di Indonesia (Saputri, 2015). Penelitian kedua mengungkap bahwa Praktik perjanjian nomine di Indonesia merupakan suatu yang tidak diizinkan, dengan kata lain merupakan suatu penyelundupan hukum (Motulo, 2018). selanjutnya penelitiannya mengungkapkan bahwa Perjanjian yang dibuat oleh warga Negara Asing dan warga negara Indonesia batal demi hukum karena tidak memenuhi syarat sah suatu perjanjian (Aprilla et al., 2018). Penelitian ini bertujuan untuk menjelaskan sistem pengaturan perjanjian pinjam nama sebagai bentuk kepemilikan tanah oleh warga negara asing di Bali dan mengetahui pertanggungjawaban notaris dalam pembuatan akta perjanjian pinjam nama atas penguasaan tanah oleh warga negara asing di Bali.

\section{METODE PENELITIAN}

Penelitian ini didesain menggunakan penelitian hukum normatif empiris yaitu penelitian hukum yang mengkaji hukum tertulis dari berbagai lini, yakni aspek teoritis, historis, filosofis, perbandingan, struktural, komposisi, lingkup materi, konsistensi definitive umum dan pasal-pasal, formalitas dan kekuatan mengikat suatu undang-undang, serta bahasa hukum yang dipergunakan. Pendekatan masalah adalah pendekatan perundang-undangan dan secaara konsep yaitu menganalisis permasalahan yang akan dibahas melalui konsep hukum yang diambil dari buku dan literatur serta pendekatan kasus yang ada relevansinya dengan permasalahan. Dalam menyusun penelitian ini, akan menggunakan bahan hukum yang diperoleh dari penelitian kepustakaan (library research), yaitu bahan hukum primer adapun bahan hukum primer yang digunakan dalam penelitian ini adalah bahan hukum yang bersumber 
dari peraturan perundang-undangan yang berkaitan dengan pokok permasalahan yang dibuat dan bahan hukum sekunder sumber bahan hukum sekunder adalah sumber bahan hukum yang memberikan penjelasan terhadap bahan hukum primer (Soekanto, 2007). Teknik pengumpulan data adalah teknik pencatatan terhadap bahan-bahan hukum yang akan digunakan dalam menganalisis permasalahan peneltian ini.

\section{HASIL DAN PEMBAHASAN}

Pengaturan Perjanjian Pinjam Nama sebagai Bentuk Kepemilikan Tanah oleh Warga Negara Asing Perjanjian innominaat atau kadang disebut trusttidak dikenal dalam sistem hukum civil law yang berlaku di Indonesia, banyaknya permasalahan yang timbul dalam suatu perjanjian ini karena perjanjian yang dibuat oleh para pihak merupakan penyelundupan hukum (Wicaksono, 2016). Dalam perundangundangan di Indonesia (KUHPerdata) belum adanya pengaturan secara khusus mengenai perjanjian pinjam nama ini karena perjanjian pinjam nama ini merupakan perjanjian yang dibuat oleh warga negara asing dengan warga negara Indonesia. Perjanjian pinjam nama ini masuk kedalam perjanjian khusus yang ada di KUHPerdata yaitu perjanjian tidak bernama atau sering disebut dengan perjanjian innominaat. Perjanjian pinjam nama ini sah dilakukan jika di dalam suatu perjanjian tersebut memenuhi syarat sahnya perjanjian, etikad yang baik serta kausa yang halal, dan tidak bertentangan dengan perundang-undangan yang ada. Perjanjian ini yang menjadi objek dari perjanjian pinjam nama ini adalah tanah hak milik yang sudah jelas diatur dalam UUPA bahwa warga Negara Asing tidak boleh memiliki tanah hak milik di Indonesia khususnya di Bali.

Peminjaman nama guna melancarkan bisnisnya, isi dari perjanjian pinjam nama harus memuat bahwa warga Negara Asing dapat menguasai tanah hak milik dalam arti menguasai adalah mengelola, memenect mengontrol, memanfaatkan (Winardi, 2017). Dalam menguasai tanah hak milik oleh warga Negara Asing, sesuai jangka waktu hak pakai (HGB) yang di tentukan adalah 20 sampai 25 tahun dan bisa di perpanjang. tetapi tidak boleh menguasai selama-lamanya, pinjam nama selama-lamanya melanggar etikad baik (penyelundupan hukum).

\section{Pertanggungjawaban Notaris dalam Pembuatan Akta Perjanjian atas Penguasaan Tanah oleh Warga Negara Asing}

Kewenangan notaris membuat akta otentik merupakan perbuatan hukum, yang mana dapat dipertanggungjawabkan pula secara hukum dan tidak memihak kepada para pihak (Maslikan \& Sukarmi, 2018). Sebagaimana telah diuraikan sebelumnya, seorang notaris yang menjalankan jabatannya menurut Undang-Undang Jabatan Notaris dapat dipertanggungjawabkan secara administratif dan perdata.

Setiap notaris wajib mematuhi Undang-Undang Jabatan Notaris, maupun peraturan perundangundangan lainnya dan setiap orang mempunyai persamaan kedudukan dihadapan hukum. Hal ini juga menjadi sumpah atau janji jabatan bagi seorang dalam menjalankan jabatan sebagai notaris. KUHPerdata juga berlaku dan wajib dipatuhi oleh notaris. Dalam kaitannya dengan pembuatan akta pinjam nama, maka pertanggungjawaban secara perdata dapat dikenakan pada notaris berdasarkan ketentuan Pasal 1365 KUHPerdata dan Pasal 1366 KUHPerdata.

Fenomena yang terjadi di Bali secara global yaitu banyak notaris tidak paham atau menguasai dasar hukum dalam membuat perjanjian pinjam nama ini. Sehingga meraka yang membuatnya salah dan melanggar ketentuan undang-undang karena ketidak tahuannya dalam membuat perjanjian pinjam namaTetapi ada beberapa notaris yang sudah paham, tetapi banyak yang tidak menguasai dasar perjanjian pinjam nama.

\section{SIMPULAN DAN SARAN Simpulan}

Adapun yang menjadi kesimpulan dari penelitian ini adalah:

1. Tidak adanya pengaturan secara khusus mengenai perjanjian pinjam nama ini dan tidak diatur dalam Kitab Undang-Undang Hukum Perdata (KUHPerdata) karena perjanjian ini masuk kedalam perjanjian khusus (perjanjian inominaat) selama tidak bertentangan dengan ketentuan tentang sahnya perjanjian dan ketentuan UUPA mengenai hak milik atas tanah. Serta perjanjian yang dilakukan oleh para pihak ini selama tidak bertentangan dengan Undang-Undang yang ada perjanjian tersebut bias berjalan lancer, jika wanprestasi yang merugikan salah satu pihak dan perjanjian yang 
dibuat bertentangan dengan Undang-Undang maka perjanjian tersebut batal demi hukum atau penyelundupan hukum.

2. Kewenangan notaris membuat akta otentik merupakan perbuatan hukum dan dipertanggungjawabkan pula secara hukum. Jabatan atau profesi notaris dalam pembuatan akta otentik merupakan jabatan yang mulya yang harus dipertanggungjawabkan baik secara hukum maupun secara etika profesi. Kepemilikan tanah oleh WNA dengan berdasarkan pada akta pinjam nama, merupakan perbuatan yang dilarang atau bertentangan dengan hukum. Pelanggaran terhadap pasal-pasal yang dimaksud dalam Pasal 84 UUJN tersebut, merupakan pelanggaran terhadap syaratsyarat formil pembuatan akta otentik.

\section{Saran}

Sesuai dengan hasil penelitian ini ada bebrapa hal yang disarankan oleh peneliti yaitu:

1. Sebaiknya akademisi dibidang memberikan pandangan kongkrit terhadap fenomena yang terjadi khususnya mengenai perjanjian pinjam nama sebagai bentuk kepemilikan tanah oleh warga Negara Asing di Bali. Dimana adanya kekaburan norma (penyelundupan hukum) mengingat perjanjian ini bertentangan dengan undang-undang serta tidak adanya pengaturan khusus dalam Kitab UndangUndang Hukum Perdata (KUHPerdata) dan Undang-Undang Pokok Agraria (UUPA) sehingga perjanjian ini lebih baik tidak di gunakan karena banyaknya permasalah yang timbul dari perjanjian tersebut, dan bertentangannya terhadap undang-undang mengakibatkan perjanjian tersebut batal demi hukum atau cacad hukum.

2. Notaris dalam menjalankan tugasnya harus mengiuti aturan atau perundang-undangan yang berlaku pada hukum positif serta mengikuti aturan tanggung jawab profesi dan etika tanggung jawab selaku notaris yang sudah diatur didalam Undang-Undang Jabatan Notaris. Serta tidak memihak salah satu pihak dalam suatu perjanjian dan tidak bertentangan dengan perundang-undangan.

\section{DAFTAR PUSTAKA}

Amalia, I. Q. A. (2018). Akibat Hukum Pembatalan Perjanjian dalam Putusan Nomor 1572 K/PDT/2015 Berdasarkan Pasal 1320 dan 1338 KUH Perdata. Jurnal Hukum Bisnis Bonum Commune, 1(1), 61-72.

Aprilla, A. P., Permadi, I., \& Efendi, L. (2018). Status Hukum Hak Milik atas Tanah Warga Negara Asing dengan Meminjam Nama Warga Negara Indonesia. Jurnal Ilmiah Pendidikan Pancasila Dan Kewarganegaraan, $3(1), 15-21$.

Harsono, B. (2002). Menuju Penyempurnaan Hukum Tanah Nasional. Universitas Trisakti.

Hutauruk, A., \& Harto, S. (2017). Pengaruh Kunjungan Wisatawan Asing terhadap Ekonomi Pariwisata Indonesia. Jom Fisip, 4(2), 1-13.

Maslikan, \& Sukarmi. (2018). Kewenangan Notaris dalam Pembuatan Akta Otentik Berkaitan dengan Kontrak Kerjasama. Jurnal Akta, 5(1), 11-16.

Motulo, N. F. (2018). Kepemilikan Properti Warga Negara Asing di Indonesia Menurut Peraturan Pemerintah Nomor 103 Tahun 2015. Lex Et Societatis, 6(10), 65-74.

Saputri, A. D. (2015). Perjanjian Nominee dalam Kepemilikan Tanah bagi Warga Negara Asing yang Berkedudukan di Indonesia. Jurnal Repertorium, II(2), 96-104.

Soekanto, S. (2007). Faktor-Faktor yang Mempengaruhi Penegakan Hukum. PT Raja Grafindo Persada.

Subekti. (2002). Hukum Perjanjian. Intermasa.

Wicaksono, L. S. (2016). Kepastian Hukum Nominee Agreement Kepemilikan Saham Perseroan Terbatas. Jurnal Hukum Ius Quia Iustum, 23(1), 42-57.

Winardi, M. (2017). Kewenangan Notaris dalam Pembuatan Akta Otentik Berkaitan dengan Kontrak Kerja Sama. Jurnal Reporetorium, 4(1), 61-72. 